
$\angle$ Research Square
Preprints are preliminary reports that have not undergone peer review.
They should not be considered conclusive, used to inform clinical practice, or referenced by the media as validated information.

\title{
Pattern and Outcome of Pediatric Traumatic Brain Injury: A Prospective Cohort Study at Hawassa University Comprehensive Specialized Hospital, Southern Ethiopia
}

\author{
Tuji Bedry \\ Dire Dawa University College of Health Sciences \\ Henok Tadele ( $\square$ henny_2007@yahoo.com ) \\ Hawassa University College of Medicine and Health Sciences
}

\author{
Research article \\ Keywords: Pediatrics, traumatic head injury, Outcome, Ethiopia \\ Posted Date: February 28th, 2019 \\ DOI: https://doi.org/10.21203/rs.2.424/v1 \\ License: (9) This work is licensed under a Creative Commons Attribution 4.0 International License. Read Full License
}




\section{Abstract}

Background Traumatic brain injury (TBI), a major public health problem, is the most common cause of death/disability in children. Glasgow coma scale is used to assess, decide treatment and follow up of TBI. TBI causes and outcome data are scarce from subSaharan Africa, non-existent from Ethiopia. We aimed to document pattern and predictors of childhood TBI outcome in a teaching hospital, Southern Ethiopia. METHODS Prospective cohort study was conducted from September 2017 to September 2018 among pediatrics TBI presented to Hawassa University Hospital. Data were collected by structured questionnaires and analyzed using SPSS version 20. Logistic regression was carried out and significant associations were declared at $p$-value of $<0.05$. RESULT During 1year period there were 4258 emergency room(ER) visits, TBI contributed to $317(7.4 \%)$ cases. The mean age of study subjects was $7.66 \pm 3.88$ years. Boys, predominantly above 5years of age, comprise $218(68.8 \%)$ of study subjects with male to female ratio of 2.2:1. Pedestrian RTA 119 (37.5\%) and falls 104 (32.8\%) were the commonest causes of TBI. Mild, moderate, and severe TBI were documented in 231(72.9\%), 61(19.2\%), and 25(7.9\%) of cases respectively. Most of TBI cases presented within 24hrs of injury 258(81.4\%). Recovery with no neurologic deficit, 267(84.2\%); focal neurologic deficit, 30(9.5\%); depressed mentation, 10(3.2\%) and death 10(3.2\%) were documented. Presence of increased intracranial pressure(ICP) at admission [AOR: 1.415 (95\% Cl: 0.458-9.557)], severe TBI [AOR: 2.103 (95\% Cl: 0.965-4.524)], presence of hyperglycemia [AOR: 2.318 (95\% Cl: 0.873-7.874)] and head computed tomographic(CT) scans of contusion, diffuse axonal injury (DAI) or intracranial bleeding [AOR: 2.45 (95\% Cl: 0.811-7.952)] were found to be predictors of TBI outcome. CONCLUSION TBI contributed to $7.4 \%$ of pediatric ER visits. Boys above 5years of age were highly affected. Pedestrian RTA and falls, early presentation (<24hrs of injury) and mild form of TBI were the common documented patterns. Presence of increased ICP, hyperglycemia, severe TBI and CT findings of contusion, DAl/intracranial bleeding were predictors of poor outcome. Public awareness on road safety, childhood safety in preventing falls/animal injuries, closer follow-up of TBI cases for ICP and glycemic controls are recommended.

\section{Background}

Traumatic brain injury (TBI) is a brain injury that occurs following a blow to head, a fall, a bullet, a high speed crash or explosion injuries. TBI could be an open (penetrating) or closed type[1]. Childhood injury requires an immediate attention given its contribution to high childhood mortality and long term disabilities. Injuries contribute to $5.4 \%(265,000-348,000)$ of childhood deaths per year worldwide[2]. In 2015, injuries resulted in 25,000 deaths among Ethiopian children 0-14years of age[3]. TBI is a single, severe and most common form of injury in children[4].

Worldwide it is estimated that TBI affects 69 million individuals each year. Low and middle income countries (LMICS) have three times high TBI burden than high income countries. Road traffic related head injuries were reported to be common in LMICS. Globally TBI is projected to be the third leading cause of death and injury by world health organization in 2020[2, 5, 6]. Pediatric TBI is reported to be the common cause of injury related death, and it commonly follows road traffic accidents and falls $[7,8]$. Western studies documented TBI contributing for $8.3 \%$ of pediatric emergency department(ED) visits, and commonly with mild severity $[9,10]$. Reports from developing countries documented TBI to be a very common public health problem with varied burden figures, commonly milder severity and most notably following motor vehicle accidents [11-17]. Road traffic accidents (RTA) and falls from height appeared to be the commonest causes of pediatric TBI. Assaults or intentional injuries are reported in minority of cases [2, 9-11, 18].

Primary brain injury involves initial tear, shear or hemorrhage. Secondary injuries, which are targets for intervention, usually involve cascades of biologic reactions following primary injury. These changes include cellular, chemical, tissue, or blood vessel changes in the brain resulting in further damage to brain tissue $[19,20]$.Severity of TBI is assessed using Glasgow coma scale (GCS) and graded into mild(13-15), moderate(9-13) and severe(<8). GCS also assists in assessing the outcome of TBI cases [6, 21, 22]. Mild TBI presents with concussion symptoms affecting physical, cognitive, and emotional (affective) domains. Various degrees of autonomic and neurologic dysfunction are seen in moderate and severe TBI cases in addition to mild TBI features [23, 24]. Head computed tomography( CT) is recommended for children presenting with drowsiness or decreased mentation, any sign of basal skull fracture, focal neurologic deficit etc[25]. Several arguments are forwarded on abandonment of skull x-ray as an investigation means for TBI [26, 27].

Acute management of TBI includes resuscitation and airway management, nutritional support, intubation for TBI with GCS $\leq 8$, follow up for increased intracranial pressure and other complications, and neurosurgical intervention[6]. Presence of cerebral edema, GCS $\leq 8$, hypoxemia, and hypernatremia were reported to be predictors of poor outcome among TBI cases $[21,22,28]$. Outcome of TBI varied in resource limited settings and neurocritical protocol for prehospital care was recommended [29]. Mortality rate ranged from $8 \%$ in western settings to $21.2 \%$ in developing regions $[7,11,29]$. Lack of prospective studies and injury data registries in most parts of Africa has made the assessment of TBI difficult [15]. No report is published in pediatric TBI in a prospective base from Ethiopia. Hence, we aimed at 
documenting the mechanisms of $\mathrm{TBI}$, treatment modalities and outcome in a prospective study at tertiary hospital where neurosurgical interventions are possible. Our study will fill the knowledge gap and assists policy makers, researchers and concerned stakeholders for planning detailed intervention.

\section{Methods}

\section{Study Area}

The study was conducted at Hawassa university comprehensive and specialized hospital (HUCSH), Hawassa, Ethiopia. Hawassa city is located $270 \mathrm{~km}$ South of Addis Ababa-Ethiopia's capital. HUCSH is the first and largest referral and teaching hospital in Southern Ethiopia. It serves a catchment population of over 18 million. The Pediatrics Department provides inpatient and outpatient services. Neurosurgical interventions are provided by Neurosurgeons, radiologic imaging including head CT are read by radiologists. The hospital has an Intensive care unit (ICU) for care of critical ill patients.

\section{Study design and period}

A prospective cohort study was carried out among pediatric TBI cases, aged between 2months and 14years, and visited HUCSH from September 2017 to September 2018. Consecutively admitted TBI cases fulfilling the predefined criteria were included in the study after informed consent was obtained from family or guardians. Cases were excluded from the study when consent is not secured.

\section{Sample size}

The sample size was calculated using single proportion formula in Epi info 7.2 with assumptions of $95 \%$ confidence interval, power of $80 \%$, percentage of outcome in exposed group - $17 \%$, odds ratio -4.2 , and the final sample size was $331[30]$.

\section{Variables}

The dependent variable was patient's outcome on discharge i.e. death, neurologic deficit or full recovery. Independent variables included socio-demographic data (age, sex, and place of residence), intent, mechanism and nature of injury, place of occurrence, severity of injury, associated extracranial injury, investigation and treatment type, and stay in the hospital.

\section{Operational definitions}

Traumatic brain injury (TBI) was defined as a brain injury that occurs following a blow to head, a fall, a bullet, a high speed crash or explosion injuries[1]. TBI severity was graded into mild, moderate and severe when GCS is 13-15, 9-13, and severe < 8[6]. Outcome was assessed using the GOS (Glasgow outcome score) during hospital discharge by physicians in charge of patient care [21, 22]. Hypotension and hypertension were considered when blood pressure for age and sex was below $50^{\text {th }}$ percentile and $\geq 95^{\text {th }}$ percentile[31]. Hypoglycemia and hyperglycemia were considered when admission random blood sugar is $<70 \mathrm{mg} / \mathrm{dl}$ and $>200 \mathrm{mg} / \mathrm{dl}[32,33]$.

\section{Data collection tool, procedure and data quality assurance}

Data were collected at first presentation of the patient to pediatric emergency room/ department, and continued during admission and at the time of discharge by trained Bachelor of Science graduate nurses and intern doctors. Data were collected using structured questionnaire and information consisting of sociodemographic characteristics, characteristics of injury (i.e. intent, mechanism, nature, and place of injury) and patient's previous medical history, clinical work up and management, duration of admitted stay and discharge outcome were collected. All consecutive TBI cases seen at pediatric emergency department of HUCSH were included after consent was obtained from family or guardian. Daily collected data were checked by supervisor resident doctor for completeness and correction was made on spot and on daily basis.

\section{Data analysis}

Data were doubled entered into excel spread sheet and analyzed using SPSS version 20 software. Descriptive statistics like percentage, mean and standard deviation were used for the presentation of demographic data and factors affecting outcome of pediatric head injury. Binary Logistic regression was used to assess the association between dependent and Independent variables. Variables with P-value < 0.05 were taken into multiple logistic regression models for controlling the possible effect of confounders and finally the variables which had independent association with outcome of TBI were identified on the basis of adjusted odds ratio(aOR), with $95 \% \mathrm{Cl}$ and $\mathrm{P}$ value $<0.05$. 


\section{Results}

\section{Sociodemographic characteristics}

There were 4258 pediatric emergency room(ER) visits and TBI contributed to 7.4\% (317) of ER visits in one year study period. A total of 317 study subjects were included, $96 \%$ response rate. From 317 study subjects, there were $218(68.8 \%)$ males and $99(31.2 \%)$ females with male to female ratio of 2.2:1. The study subjects aged from 7 months to 14 years; mean age of $7.66 \pm 3.82$ years. School age groups, $5-10$ years and adolescents, $10-14$ years contributed for $36.9 \%$ (117) and 36.3\%(115) of TBI. One hundred eighty three (57.7\%) of study subjects came from southern nations, nationalities and peoples regional state (SNNPR) while the rest 134(42.3\%) came from the neighboring Oromia and Somali Ethiopian regional states (See Table 1).

Boys were predominantly affected and they accounted for $65.8 \%, 68.3 \%$ and $71.3 \%$ of TBI in under-fives, school age and adolescent age groups respectively.

\section{Pattern and mechanism of traumatic brain injury}

TBI were caused mainly by RTA (road traffic accidents), 144 (45.4\%) cases. Out of these, majority were pedestrians, 120 (83.3\%) while 25 (17.3\%) were occupants in vehicles. The other TBI causes were falls, 104 (32.8\%); fighting/violence, 40 (12.6\%); animal bite or kick injury, 28 (8.8\%) and one case of assault (child maltreatment). Most preschool falls occurred at home $29(60.7 \%)$ while $94.1 \%$ (32) of school age and $97.6 \%$ (41) of adolescent falls happened outdoor. Eighty three $(79.8 \%)$ of falls and $84(58.3 \%)$ of road traffic accidents occurred in boys (See figure 1).

Concerning timing of presentation, most of study subjects presented within 24 hours of injury, $258(81.4 \%)$. Thirty one (9.8\%) and $28(8.8 \%)$ of TBI cases presented between 24 hours and 72 hours, and after 72 hours of injury (See table 2 ).

Most injuries were unintentional injuries, $87.4 \%$ (277). Almost all of intentional injuries, 38 (97.5\%) were due to fighting with only one case of child maltreatment. Eight nine (28\%) of TBI cases had lost consciousness at the time of presentation. From study subjects, $26(8.2 \%)$ exhibited seizure, $40(12.6 \%)$ had pupillary abnormality sign and 60(18.9\%) showed sign of increased intracranial pressure (ICP). Hypertension and depressed mentation were the most common manifestation of increased ICP, each accounting for 22(6.9\%) of increased ICP cases. Vomiting 16(5\%) was the other common increased ICP feature (See table 2).

Most pediatric TBI cases were conscious at the time of presentation, 195 (61.5\%) had GCS of 15/15. The least GCS was 3 in 4 cases and mean GCS at admission was $13.4 \pm 2.7$. Up on grading of TBI severity, mild TBI was the commonest type, 231(72.9\%) with moderate TBI and severe TBI contributing for $61(19.2 \%)$ and $25(7.9 \%)$ of study subjects. Mild TBI was caused by all mechanisms of injury while moderate and severe injuries were mainly caused by RTA and fall in $96.7 \%(59)$ and $100 \%(25)$ of cases. Hypotension and hyperglycemia on presentation were documented in $9(2.8 \%)$ and $20(6.3 \%)$ of TBI cases (See table 2$)$.

Skull X-ray was done in 177 (55.8\%) of study subjects and skull fractures were found in 100(31.5\%) TBI cases: linear skull fractures, 27 (8.5\%); depressed skull fractures, 72 (22.7\%); basal skull fracture, 1(0.3\%). Head CT scan was done in 70.7\% (224) of TBI cases and intracranial hematomas, $6 \%$ (14): 3 epidural, 6 subdural, 4 intracerebral and 1 subarachnoid hemorrhage were documented. Other head CT findings were cerebral contusion and diffuse axonal injury in 30 (13.4\%); simple skull fractures without intracranial bleeding in 94 (41.9\%), and depressed skull fractures with contusion or intracranial bleeding in $36(16 \%)$ of cases. Head CT scan was normal in 50 $(15.8 \%)$ of TBI. Head CT findings in fatal cases were depressed skull fractures with extensive intracerebral hemorrhages in $4(40 \%)$, diffuse axonal injury (DAl) in 4 (40\%). Head CT was not done in 2 cases (10\%) (See table 2).

Associated extracranial injuries were reported in 256 (80.7\%) of TBI. From these, soft tissue injury is the commonest form, 179 (56.5\%) followed by extremity bone fracture $70(22.1 \%)$, chest or abdominal injury $6(1.9 \%)$ and one case of vertebral bone injury (See table 3 ).

\section{Management and outcome}

One hundred twenty nine $(72.2 \%)$ of TBI were managed conservatively while $88(27.8 \%)$ underwent various surgical operations within the first 01 week of presentation. Most operated cases aged 5 to 10 years, 48 /88 (55\%). None of the operated patient died. The surgical indications for operations were evacuation of epidural and subdural hematoma in 4 (4.5\%); wound debridement for compound skull fracture in 19 (21.3\%) and depressed skull fracture elevation in 66 (74.2\%) (See table 3). 
Regarding duration of hospitalization, majority of TBI cases stayed from 4 to 7 days, $34 \%$ (108) while $78(24.6 \%)$ were discharged with in 24hours of arrival. Prolonged hospitalization ( $\geq 1$ month) was seen in 2 patients with severe TBI and extremity fracture with extensive soft tissue injury. The average hospitalization days for cases who died was 4.5 days (median 2 days), and $5 / 10(50 \%)$ of deaths occurred within the first 3days of admission (See table 4).

Concerning outcome at discharge, 303(95.6\%) study subjects recovered from the injury: 267(84.2\%) with good recovery without neurologic deficit, 30(9.5\%) with focal neurologic deficit and 10(3.2\%) with depressed mentation. Ten (3.2\%) deaths were documented and 2 cases were referred to another hospital and 2 went against medical advice (See table 3 )

\section{Factors affecting outcome}

On bivariate analysis factors significantly associated with outcome of pediatric TBI with $95 \% \mathrm{Cl}$ and $\mathrm{p}$ value $<0.05$ were: comorbid illness, loss of consciousness and convulsion at presentation, increased ICP sign, severity of head injury, presence of hypotension, hyperglycemia on presentation, and head CT scan findings.

On multivariable logistic regression, presence of increased ICP at admission was associated with 1.4 times increased chances of death, [AOR: 1.415 (95\% Cl: 0.458-9.557)]. Severe TBI was associated with double risk of death compared with moderate and mild TBI, [AOR: 2.103 (95\% Cl: 0.965-4.524)]. Presence of hyperglycemia [AOR: 2.318 (95\% Cl: 0.873-7.874)] and CT scan finding of contusion, DAl or intracranial bleeding [AOR: 2.45 (95\% Cl: 0.811-7.952)] were also found to be significantly associated with outcome of pediatric TBI (See table 4).

\section{Discussion}

In our study, boys and children above 5 years of age predominated. This finding is in agreement with Nigerian, South African and Tunisian studies. This could be related to boy's risk-prone behavior resulting in high energy transfer and their outdoor engagement [14,30, 34-37]. Concerning mechanism of injury, unintentional pedestrian RTA and falls were the commonest causes followed by intentional fighting/violence injuries. This is in line with most of the studies done in developing countries $[2,8,18,22,30,34,37-39]$.

Most of our study subjects presented within 24hours of injury and had mild form of TBI. This is in line with reports from Nigeria and Tunisia $[30,34,38,40]$. However severe TBI was the commonest form in another Nigerian and Tunisian studies. The possible reason for the noted difference could be exclusion of mild TBI cases not meeting admission criteria in Nigerian study and all studied subjects in Tunisian study were ICU(intensive care unit) admitted patients with severe TBI or severity feature [30, 39]. Our study subjects had hypotension, lost consciousness, convulsion and increased intracranial pressure sign at presentation. Comparable reports were documented in other studies [30,37].

In this study, subjects were evaluated with random blood sugar, skull X-ray and head CT scan at presentation. Most of the subjects had normal glucose level with hyperglycemia documented in $6.3 \%$ of TBI cases. Head CT scan was taken in $70.7 \%$ of study subjects and showed various types of skull bone fractures, brain contusion, intracranial bleeding and diffuse axonal injury. These findings are in agreement with studies done in India, Tunisia and Nigeria, and head CT scan requests conform to the recommended neurosurgical practice $[22,25,30,37,39]$.

In our study, associated extracranial injuries were documented in $80 \%$ of the study subjects with soft tissue injury being the commonest followed by extremity bone fracture. Reports from Nigeria and Nepal documented similar findings $[18,40]$. Most of the subjects in our study are managed conservatively (72.2\%), while neurosurgical interventions like depressed skull elevation, irrigation and debridement, hematoma evacuation were the common procedures. Studies from India, South Africa, Nigeria and Tunisia have documented similar findings [37-39, 41]. Concerning hospital stay, majority of our study subjects stayed from 4 to 7 days and a quarter $(24.6 \%)$ was discharged in the first 24 hours of admission. Shorter hospital stay could be due to the higher percentage of milder forms of TBI in our study. These findings are comparable with other similar studies done in Africa and china [22, 29, 41, 42].

In this study, good functional outcome (recovery without any neurologic deficit) was documented in $84.2 \%(95 \% \mathrm{Cl}, 80.2-88.1)$ of study subjects. This is higher than Indian and Chinese studies [37, 42]. It is lower than Nigerian and South African Studies [34, 39, 41]. Ten (3.2\%, 95\% Cl: $1.5-5.7 \%)$ of our study subjects died. This is comparable with South African report[41] but it is lower than Chinese, Nigerian and studies[34, 37, 38, 40,42]. Differences in outcome could be explained by the varied health facilities capacities, severity and mode of head injury and age of inclusion, the above Nigerian study included children up to 18years of age. Additionally, majority of our study subjects have milder form of TBI. 
In the current study, severe TBI was associated with doubled risk of death when compared with mild and moderate head injuries. This finding is supported by Nigerian and Indian reports [39, 40,43]. Severe TBI is associated with primary areflexia and secondary brain edema, which predicts the outcome of the patient[44]. Head CT scan findings of contusion, diffuse axonal injury and intracranial bleedings were associated with 2.45 times higher chances of death when compared with normal head CT cases. This is in agreement with Tunisian and Nigerian studies [22,30,39]. Diffuse axonal injury that occurs in TBI is reported to be secondary to axonal swelling, calcium mediated irreversible blockade of axonal transport, swollen endoplasmic reticulum etc. These will be evident on head CT as cerebral contusion, intracerebral hematoma and subarachnoid hemorrhages. It is reported these findings predict poor outcome among TBI cases with highest accuracy [45-47].

Our study documented 1.42 times higher chances of death and neurologic disability among TBI cases who presented with increased ICP signs when compared with those without increased ICP signs. This is in line with Tunisian and Argentinian studies [22, 30, 48]. Glial swelling with narrowed lumina of the microvasculature due to podocytic process swelling results in increased ICP. Diffuse cerebral ischemia also results in calcium hemostatic imbalance, activation of anaerobic metabolism. Increased ICP clinically presents as hypoxemia, seizure, mental level deterioration and neurologic deficits $[49,50]$.

In this study, admission hyperglycemia was associated with 2.32 fold higher chance of death and neurologic disability. Similar findings were reported in studies done at Turkey and Singapore [32, 51]\{Danisman, 2015 \#98;Chong, 2015 \#99;Chong, 2015 \#58\}. Impaired cerebral mitochondrial dysfunction following TBI is thought to result in hyperglycemia $[52,53]$ though detailed mechanisms are yet to be studied [54]. Our study limitations are increased intracranial pressure was assessed clinically and long term follow up neurologic outcomes was not determined as outcome was assessed on hospital discharge.

\section{Conclusions}

In our study, boys and children above 5years of age were highly affected by TBI. Pedestrian RTA, falls, fights, animal related injuries were the commonest mechanisms of injuries. Early presentation (<24hrs) and mild form of TBI were the commonest clinical presentations. Various forms of skull vault fractures: hemorrhage, contusion and axonal injuries were documented on head CT-scan. Majority of our study subjects were managed conservatively and recovered without neurologic deficits. Death was documented in $10(3.2 \%)$ of study subjects. Increased ICP and hyperglycemia at admission, severe TBI and head CT findings of contusion, diffuse axonal injury or intracranial bleeding were found to be predictors for TBI outcome. Public awareness on road safety needs to be strengthened. Parents or guardians need to be watchful in preventing fall and animal related pediatric injuries. Closer follow up of TBI cases for ICP and proper glycemic controls are recommended. Head CT-scan imaging should be considered in pediatric TBI.

\section{Abbreviations}

AOR- adjusted odd ratio; Cl-confidence interval; COR- crude odd ratio; CT- computed tomography; DAl-diffuse axonal injury; DSF depressed skull fracture; GCS- Glasgow coma scale; GOS- Glasgow outcome score; HUCSH-Hawassa university comprehensive specialized hospital; ICP-intracranial pressure; OR- odds ratio; RTA- road traffic accident; SNNPR- southern nations, nationalities and peoples region; TBI- traumatic brain injury.

\section{Declarations}

\section{Ethical approval and consent to participate}

Ethical approval of the research protocol was obtained from institutional review board of Hawassa University. Written permission was secured from the hospital administration. Purpose of the study was explained to participants and consent was obtained from the parent or legal guardian of the child and assent was secured from adolescents. Confidentiality was assured by excluding patient names and by respecting the study subjects right not to participate or withdraw at any point from the study. Patient with no caretaker and who had severe head injury were excluded from study.

\section{Consent for publication}

Not applicable 


\section{Availability of data and material}

The datasets analyzed during this study is available from the corresponding author on reasonable request.

\section{Competing interests}

The authors declare that they have no competing interests.

\section{Funding}

Funding was received from Hawassa University, school of Graduate studies. The funding was used for the design and study data collection, analysis, interpretation of data and in writing the manuscript.

\section{Authors' contributions}

TB: wrote the draft proposal in consultation with HT, monitored data collection, entered data, analyzed, and wrote draft report. HT: conceived the idea and critically contributed to the design, analysis and interpretation of findings, wrote the current manuscript in its current form. Both authors have read and approved the manuscript for publication.

\section{Acknowledgments}

Not applicable

\section{References}

1. World Health Organization. Disability and Rehabilitation Team, United States. Dept. of Defense\& Drucker Brain Injury Center. (2004). Rehabilitation for persons with traumatic brain injury. Geneva : World Health Organization.

2. GBD 2015 Mortality and Causes of Death Collaborators. Global, regional, and national life expectancy, all-cause mortality, and causespecific mortality for 249 causes of death, 1980-2015: a systematic analysis for the Global Burden of Disease Study 2015. Lancet. 2016;388(10053):1459-1544.

3. Li Q, Alonge O, Lawhorn C, Ambaw Y, Kumar S, Jacobs T, Hyder AA. Child injuries in Ethiopia: A review of the current situation with projections. PLoS One.2018;13(3)

4. World Health Organization. World report on child injury prevention. 2008; Geneva: World Health organization.

5. Dewan MC, Rattani A, Gupta S, Baticulon RE, Hung YC, Punchak M, et al. Estimating the global incidence of traumatic brain injury. J Neurosurg.2018; doi: 10.3171/2017.10.JNS17352

6. DinsmoreJ. Traumatic brain injury: an evidence-based review of management. Continuing Education in Anaesthesia Critical Care \& Pain, 2013; 13(6): 189-195.

7. Hill CS, McLean AL, Wilson MH. Epidemiology of Pediatric Traumatic Brain Injury in a Dense Urban Area Served by a Helicopter Trauma Service. Pediatr Emerg Care.2018;34(6):426-430.

8. Punchak M, Abdelgadir J, Obiga O, Itait M, Najjuma JN, Haglund MM, et al. Mechanism of Pediatric Traumatic Brain Injury in Southwestern Uganda: A Prospective Cohort of 100 Patients. World Neurosurg.2018;doi: 10.1016/j.wneu.2018.02.191

9. Amaranath JE, Ramanan M, Reagh J, Saekang E, Prasad N, Chaseling R, et al. Epidemiology of traumatic head injury from a major paediatric trauma centre in New South Wales, Australia. ANZ J Surg.2014;84(6):424-8.

10. Avraham JB, Bhandari M, Frangos SG, Levine DA, Tunik MG, DiMaggio CJ. Epidemiology of paediatric trauma presenting to US emergency departments: 2006-2012. Inj Prev. 2017;doi: 10.1136/injuryprev-2017-042435. 
11. Aenderl I, Gashaw T, Siebeck M, Mutschler W. Head injury-a neglected public health problem: a four-month prospective study at Jimma University Specialized Hospital, Ethiopia. Ethiop J HealthSci. 2014;24(1):27-34.

12. Buitendag JJP, Kong VY, Bruce JL, Laing GL, Clarke DL, Brysiewicz P. The spectrum and outcome of paediatric traumatic brain injury in KwaZulu-Natal Province, South Africa has not changed over the last two decades. S Afr Med J.2017;107(9):777-780

13. Webster J, Taylor A, Balchin R. Traumatic brain injury, the hidden pandemic: A focused response to family and patient experiences and needs. S Afr Med J.2015;105(3):195-8

14. Schrieff LE, Thomas KG, Dollman AK, Rohlwink UK, Figaji AA. Demographic profile of severe traumatic brain injury admissions to Red Cross War Memorial Children's Hospital, 2006 - 2011. S Afr Med J.2013;103(9):616-20

15. Chichom-Mefire A, Nwanna-Nzewunwa OC, Siysi VV, Feldhaus I, Dicker R, Juillard C. Key findings from a prospective trauma registry at a regional hospital in Southwest Cameroon. PLoS One.2017;doi: 10.1371/journal.pone.0180784

16. Getachew S, Ali E, Tayler-Smith K, Hedt-Gauthier B, Silkondez W, Abebe D, et al. The burden of road traffic injuries in an emergency department in Addis Ababa, Ethiopia. Public Health Action.2016;6(2):66-71

17. Mahdian M, Sehat M, Fazel MR, Moraveji A, Mohammadzadeh M. Epidemiology of Urban Traffic Accident Victims Hospitalized More Than 24 Hours in a Level III Trauma Center, Kashan County, Iran, During 2012-2013. Arch TraumaRes. 2015;doi: 10.5812/atr.4(2)2015.28465.

18. Gupta PP, Malla GB, Bhandari R, Shah Kalawar RP, Mandal M. Patterns of Injury and Mortality in Pediatric Patients Attending Emergency Department in a Tertiary Care Center in Eastern Nepal. JNMA J Nepal Med Assoc. 2017;56(207):331-334.

19. Park E, Bell JD, Baker AJ.Park, E., J.D. Bell, and A.J. Baker. Traumatic brain injury: can the consequences be stopped? CMAJ.2008;178(9):1163-70

20. Werner C, Engelhard K. Pathophysiology of traumatic brain injury. Br J Anaesth.2007;99(1):4-9.

21. Heather NL, Derraik JG, Beca J, Hofman PL, Dansey R, Hamill J, et al. Glasgow Coma Scale and outcomes after structural traumatic head injury in early childhood. PLoS One.2013;doi: 10.1371/journal.pone.0082245.

22. Bahloul M, Chaari A, Chabchoub I, Medhyoub F, Dammak H, Kallel H, et al. Outcome analysis and outcome predictors of traumatic head injury in childhood: Analysis of 454 observations. J Emerg Trauma Shock.2011;4(2):198-206

23. Corwin DJ, Grady MF, Joffe MD, Zonfrillo MR. Pediatric Mild Traumatic Brain Injury in the Acute Setting. Pediatr Emerg Care.2017;33(9):643-649

24. Jochems D, van Wessem KJP, Houwert RM, Brouwers HB, Dankbaar JW, van Es MA, et al. Outcome in Patients with Isolated Moderate to Severe Traumatic Brain Injury. Crit Care Res Pract. 2018 ;2018:3769418

25. Yates D, Aktar R, Hill J; Guideline Development Group. Yates, D., et al., Assessment, investigation, and early management of head injury: summary of NICE guidance. BMJ.2007;335(7622):719-20.

26. Mossop D, Soysa S.The use of skull X-rays in head injury in the emergency department-a changing practice. Ann R Coll Surg Engl. 2005;87(3):188-90.

27. Leaman AM, Rysdale E. Can we abolish skull x rays for head injury? Arch Dis Child. 2006;91(4):374.

28. Ghaffarpasand F, Razmkon A, Dehghankhalili M. Glasgow Coma Scale Score in Pediatric Patients with Traumatic Brain Injury; Limitations and Reliability. Bull Emerg Trauma. 2013;1(4):135-6.

29. Fink EL, von Saint Andre-von Arnim A, Kumar R, Wilson PT, Bacha T, Aklilu AT, et al. Traumatic Brain Injury and Infectious Encephalopathy in Children From Four Resource-Limited Settings in Africa. Pediatr Crit Care Med. 2018;19(7):649-657.

30. Bahloul M, Chelly H, Chaari A, Chabchoub I, Haddar S, Herguefi L, et al. Isolated traumatic head injury in children: Analysis of 276 observations. J Emerg Trauma Shock.2011;4(1):29-36

31. Samuels J, Samuel J. New guidelines for hypertension in children and adolescents. J Clin Hypertens (Greenwich).2018;20(5):837839

32. Chong SL, Harjanto S, Testoni D, Ng ZM, Low CY, Lee KP, et al. Early Hyperglycemia in Pediatric Traumatic Brain Injury Predicts for Mortality, Prolonged Duration of Mechanical Ventilation, and Intensive Care Stay. Int J Endocrinol.2015;2015:719476.

33. Balijepalli C, Druyts E, Siliman G, Joffres M, Thorlund K, Mills EJ. Hypoglycemia: a review of definitions used in clinical trials evaluating antihyperglycemic drugs for diabetes. Clin Epidemiol.2017;9:291-296

34. NnadiMO, Bankole OB, Fente BG. Epidemiology and treatment outcome of head injury in children: A prospective study. J Pediatr Neurosci. 2014;9(3):237-41 
35. Collins NC, Molcho M, Carney P, McEvoy L, Geoghegan L, Phillips JP, et al. Are boys and girls that different? An analysis of traumatic brain injury in children. Emerg Med J.2013;30(8):675-8

36. McKinlayA, Kyonka EG, Grace RC, Horwood LJ, Fergusson DM, MacFarlane MR. An investigation of the pre-injury risk factors associated with children who experience traumatic brain injury. Inj Prev. 2010;16(1):31-5

37. Satapathy MC, Dash D, Mishra SS, Tripathy SR, Nath PC, Jena SP. Spectrum and outcome of traumatic brain injury in children <15 years: A tertiary level experience in India. Int J Crit IIIn Inj Sci.2016;6(1):16-20

38. Emejulu JK, Shokunbi MT. Aetiological patterns and management outcome of paediatric head trauma: one-year prospective study. Niger J Clin Pract, 2010. 13(3): p. 276-9.

39. Udoh DO, Adeyemo AA. Traumatic brain injuries in children: A hospital-based study in Nigeria. Afr J Paediatr Surg.2013;10(2):154-9

40. Odebode TO, Abubakar AM. Childhood head injury: causes, outcome, and outcome predictors. A Nigerian perspective. Pediatr Surg Int.2004;20(5):348-52.

41. Okyere-Dede EK, Nkalakata MC, Nkomo T, Hadley GP, Madiba TE. Paediatric head injuries in the Kwazulu-Natal Province of South Africa: a developing country perspective. Trop Doct. 2013;43(1):1-4

42. Shao J, Zhu H, Yao H, Stallones L, Yeates K, Wheeler K, et al. Characteristics and Trends of Pediatric Traumatic Brain Injuries Treated at a Large Pediatric Medical Center in China, 2002-2011. PLoS One.2012; doi: 10.1371/journal.pone.0051634

43. Yattoo GH, Tabish SA, Afzal WM, Kirmani A. Factors influencing outcome of head injury patients at a tertiary care teaching hospital in India. Int J Health Sci (Qassim).2009;3(1):59-62

44. Feickert HJ, Drommer S, Heyer R. Severe head injury in children: impact of risk factors on outcome. J Trauma.1999;47(1):33-8

45. AdamsJH, Graham DI, Gennarelli TA, Maxwell WL. Diffuse axonal injury in non-missile head injury. J Neurol Neurosurg Psychiatry. 1991;54(6):481-3.

46. Blumbergs PC, Jones NR, North JB. Diffuse axonal injury in head trauma. J Neurol Neurosurg Psychiatry. 1989;52(7):838-41

47. Fearnside MR, Cook RJ, McDougall P, McNeil RJ. The Westmead Head Injury Project outcome in severe head injury. A comparative analysis of pre-hospital, clinical and CT variables. Br J Neurosurg. 1993;7(3):267-79.

48. Vavilala MS, Lujan SB, Qiu Q, Bell MJ, Ballarini NM, Guadagnoli N, et al. Intensive care treatments associated with favorable discharge outcomes in Argentine children with severe traumatic brain injury: For the South American Guideline Adherence Group. PLoS One.2017; doi: 10.1371/journal.pone.0189296

49. Siesjö BK.Pathophysiology and treatment of focal cerebral ischemia. Part l: Pathophysiology. 1992. J Neurosurg.2008;108(3):61631.

50. Schröder ML, Muizelaar JP, Bullock MR, Salvant JB, Povlishock JT. Focal ischemia due to traumatic contusions documented by stable xenon-CT and ultrastructural studies. J Neurosurg.1995;82(6):966-71.

51. Danisman B, Yilmaz MS, Isik B, Kavalci C, Yel C, Solakoglu AG, et al. Analysisofthe correlation between blood glucose level and prognosis in patients younger than 18 years of age who had head trauma. World J Emerg Surg.2015; 10:8

52. VerweijBH, Muizelaar JP, Vinas FC, Peterson PL, Xiong Y, Lee CP. Impaired cerebral mitochondrial function after traumatic brain injury in humans. J Neurosurg. 2000 Nov;93(5):815-20.

53. Hovda DA, Lee SM, Smith ML, Von Stuck S, Bergsneider M, Kelly D, et al. The neurochemical and metabolic cascade following brain injury: moving from animal models to man. J Neurotrauma.1995;12(5):903-6.

54. CochranA, Scaife ER, Hansen KW, Downey EC. Hyperglycemia and outcomes from pediatric traumatic brain injury. J Trauma. 2003;55(6):1035-8.

\section{Tables}

Table 1: Sociodemographic characteristics of pediatric traumatic brain injury at HUCSH from September 2017 to September 2018 


\begin{tabular}{|c|c|c|c|c|}
\hline No. & Variable & Category & Number (n) & Percentage (\%) \\
\hline \multirow[t]{3}{*}{1} & \multirow[t]{3}{*}{ Age (years) } & $<5$ & 85 & 26.8 \\
\hline & & $5-10$ & 117 & 36.9 \\
\hline & & $10-14$ & 115 & 36.3 \\
\hline \multirow[t]{2}{*}{2} & \multirow[t]{2}{*}{ Gender } & Male & 218 & 68.8 \\
\hline & & Female & 99 & 31.2 \\
\hline \multirow[t]{5}{*}{3} & \multirow[t]{5}{*}{ Parental occupation } & Employee & 75 & 23.7 \\
\hline & & Merchant & 65 & 20.5 \\
\hline & & Farmer & 173 & 54.6 \\
\hline & & Driver & 2 & 0.6 \\
\hline & & Other & 2 & 0.6 \\
\hline \multirow[t]{4}{*}{4} & \multirow[t]{4}{*}{ Place of residence } & Hawassa city & 112 & 35.3 \\
\hline & & Oromia & 133 & 42 \\
\hline & & Other SNNPR & 71 & 22.4 \\
\hline & & Somali & 1 & 0.3 \\
\hline \multirow[t]{4}{*}{5} & \multirow[t]{4}{*}{ Chronic illness } & No & 313 & 98.7 \\
\hline & & $\begin{array}{l}\text { Severe } \\
\text { acute malnutrition }\end{array}$ & 2 & 0.6 \\
\hline & & Epilepsy & 1 & 0.3 \\
\hline & & Other & 1 & 0.3 \\
\hline
\end{tabular}

Table 2- Pattern and mechanism of pediatric traumatic head injury at HUCSH from September 2017 to September 2018 


\begin{tabular}{|c|c|c|c|}
\hline No. & Characteristics of traumatic head injury & Sub classification & $\mathrm{N}(\%)$ \\
\hline \multirow[t]{5}{*}{1} & \multirow[t]{5}{*}{ Mechanism of injury } & Road Traffic Accident & $144(45.4 \%)$ \\
\hline & & Falls & $104(32.8 \%)$ \\
\hline & & Fighting & $40(12.6 \%)$ \\
\hline & & Animal kick or bite & $28(8.8 \%)$ \\
\hline & & Assault/ child abuse & $1(0.3 \%)$ \\
\hline \multirow[t]{3}{*}{2} & \multirow[t]{3}{*}{ Time of arrival after injury } & $<24$ hour & $258(81.4 \%)$ \\
\hline & & 1-3 day & $31(9.8 \%)$ \\
\hline & & $>3$ day & $28(8.8 \%)$ \\
\hline \multirow[t]{4}{*}{4} & \multirow{4}{*}{ Place of occurrence } & Home & $29(9.1 \%)$ \\
\hline & & Outdoor & $143(45.1 \%)$ \\
\hline & & Occupant in vehicle & $25(7.9 \%)$ \\
\hline & & Pedestrian & $120(37.9 \%)$ \\
\hline \multirow[t]{2}{*}{5} & \multirow[t]{2}{*}{ Loss of consciousness at presentation } & No & $228(71.9 \%)$ \\
\hline & & Yes & $89(28.1 \%)$ \\
\hline \multirow[t]{2}{*}{6} & \multirow[t]{2}{*}{ Convulsion at presentation } & No & $291(91.8 \%)$ \\
\hline & & Yes & $26(8.2 \%)$ \\
\hline \multirow[t]{2}{*}{7} & \multirow[t]{2}{*}{ Increased ICP* } & No & $257(81.1 \%)$ \\
\hline & & Yes & $60(18.9 \%)$ \\
\hline \multirow[t]{3}{*}{8} & \multirow[t]{3}{*}{ Sign and symptom of increased ICP } & Vomiting & $16(5.1 \%)$ \\
\hline & & Hypertension & $22(6.9 \%)$ \\
\hline & & Decreased mentation & $22(6.9 \%)$ \\
\hline \multirow[t]{4}{*}{9} & \multirow[t]{4}{*}{ Pupillary sign } & Unilaterally fixed & $22(6.9 \%)$ \\
\hline & & Symmetrically fixed & $3(0.9 \%)$ \\
\hline & & Midsized \& reactive & $277(87.4 \%)$ \\
\hline & & Bilaterally dilated & $15(4.8 \%)$ \\
\hline \multirow[t]{3}{*}{10} & \multirow[t]{3}{*}{ Severity of TBI** } & Mild TBI & $231(72.9 \%)$ \\
\hline & & Moderate TBI & $61(19.2 \%)$ \\
\hline & & Severe TBI & $25(7.9 \%)$ \\
\hline \multirow[t]{6}{*}{11} & \multirow[t]{6}{*}{ Head CT ${ }^{\&}$ Scan finding } & Normal & $50(15.8 \%)$ \\
\hline & & Skull fracture & $94(29.7 \%)$ \\
\hline & & DSF*** with contusion, DAI+, Intracranial bleeding & $36(11.4 \%)$ \\
\hline & & Contusion/DAI & $30(9.5 \%)$ \\
\hline & & Intracranial bleeding & $14(4.4 \%)$ \\
\hline & & Not done & $93(29.3 \%)$ \\
\hline \multirow[t]{4}{*}{12} & \multirow[t]{4}{*}{ Skull X-ray finding } & Normal & $77(24.3 \%)$ \\
\hline & & Linear skull fracture & $27(8.5 \%)$ \\
\hline & & Depressed skull fracture & $72(22.7 \%)$ \\
\hline & & Not done & $141(44.5 \%)$ \\
\hline \multirow[t]{2}{*}{13} & \multirow[t]{2}{*}{ Hypotension on admission } & No & $308(97.2 \%)$ \\
\hline & & Yes & $9(2.8 \%)$ \\
\hline \multirow[t]{2}{*}{14} & \multirow[t]{2}{*}{ Hyperglycemia on admission } & No & $297(93.7 \%)$ \\
\hline & & Yes & $20(6.3 \%)$ \\
\hline
\end{tabular}

*Intracranial pressure, ${ }^{* *}$ Traumatic Brain Injury, CT\& Computed tomography, ${ }^{* * *}$ Depressed skull fracture, +Diffuse Axonal injury 


\begin{tabular}{|c|c|c|c|}
\hline S. No & Head injury Characteristics & Sub classification & $\mathrm{N}(\%)$ \\
\hline \multirow[t]{5}{*}{1} & \multirow[t]{5}{*}{ Associated Extracranial injury } & No injury & $61(19.2 \%)$ \\
\hline & & Soft Tissue Injury & $179(56.5 \%)$ \\
\hline & & Extremity bone fracture & $70(22.1 \%)$ \\
\hline & & Chest/Abdominal injury & $6(1.9 \%)$ \\
\hline & & Vertebral bone fracture & $1(0.3 \%)$ \\
\hline \multirow[t]{2}{*}{2} & \multirow[t]{2}{*}{ Management type } & Surgical & $88(27.8 \%)$ \\
\hline & & Conservative & $229(72.2 \%)$ \\
\hline \multirow[t]{4}{*}{3} & \multirow[t]{4}{*}{ Type of surgical intervention } & Burr hole & $2(0.6 \%)$ \\
\hline & & Elevation & $66(20.8 \%)$ \\
\hline & & Craniotomy & $2(0.6 \%)$ \\
\hline & & Irrigation \& debridement & $19(6.0 \%)$ \\
\hline \multirow[t]{4}{*}{4} & \multirow[t]{4}{*}{ Condition on discharge } & Survived/recovered & $303(95.6 \%)$ \\
\hline & & Died & $10(3.2 \%)$ \\
\hline & & Referred & $2(0.6 \%)$ \\
\hline & & Left against medical advice & $2(0.6 \%)$ \\
\hline \multirow[t]{3}{*}{5} & \multirow[t]{3}{*}{ Neurologic outcome at discharge } & No Deficit & $267(84.2 \%)$ \\
\hline & & Focal deficit & $30(9.5 \%)$ \\
\hline & & Depressed mentation & $10(3.2 \%)$ \\
\hline \multirow[t]{5}{*}{6} & \multirow[t]{5}{*}{ Duration of hospital stay } & $\leq 24$ hours & $78(24.6 \%)$ \\
\hline & & 1-3 days & $64(20.2 \%)$ \\
\hline & & $4-7$ days & $108(34.1 \%)$ \\
\hline & & 8 days -01 month & 65 (20.5\%) \\
\hline & & $\geq 1$ month & $2(0.6 \%)$ \\
\hline
\end{tabular}

Table 4: Multivariable logistic regression analysis of factors associated with pediatric traumatic brain injury at $\mathrm{HUCSH}$ (n=317) 


\begin{tabular}{|c|c|c|c|c|c|c|}
\hline No & Variables & Categories & No. (\%) & $\begin{array}{l}\text { COR* } \\
(95 \% \mathrm{CI})\end{array}$ & $\begin{array}{l}\text { AOR** } \\
(95 \% \mathrm{CI})\end{array}$ & P-value \\
\hline \multirow[t]{2}{*}{1} & Hyperglycemia at presentation & No & $297(93.7 \%)$ & $0.135(0.091-0.200)$ & \multirow{2}{*}{$\begin{array}{l}2.318 \\
(0.873-7.874)\end{array}$} & \multirow[t]{2}{*}{$\mathrm{p}=0.003$} \\
\hline & & Yes & $20(6.3 \%)$ & $4.461(1.855-10.728)$ & & \\
\hline \multirow[t]{2}{*}{2} & Increased $\mathrm{ICP}^{+}$sign & No & $257(81.1 \%)$ & $0.054(0.028-0.105)$ & \multirow{2}{*}{$\begin{array}{l}1.415 \\
(0.458-9.557)\end{array}$} & \multirow[t]{2}{*}{$\mathrm{P}=0.002$} \\
\hline & & Yes & 60 (18.9\%) & $2.757(1.951-3.895)$ & & \\
\hline \multirow[t]{3}{*}{3} & $\begin{array}{l}\text { Severity of } \mathrm{TBI}^{\#} \\
\text { at presentation }\end{array}$ & Mild TBI & $231(72.9 \%)$ & $0.0503(0.023-0.121)$ & \multirow[t]{3}{*}{$\begin{array}{l}2.553 \\
(0.965-4.524)\end{array}$} & \multirow[t]{3}{*}{$\mathrm{P}=0.029$} \\
\hline & & Moderate & $61(19.2 \%)$ & $1.904(1.547-2.343)$ & & \\
\hline & & Severe & $25(7.9 \%)$ & & & \\
\hline \multirow[t]{2}{*}{4} & $\mathrm{CT}^{\%}$ scan finding & Normal or skull fracture & $134(45.5 \%)$ & $0.040(0.013-0.124)$ & \multirow[t]{2}{*}{$\begin{array}{l}2.45 \\
(0.811-7.952)\end{array}$} & \multirow[t]{2}{*}{$\mathrm{P}=0.005$} \\
\hline & & Contusion, $\mathrm{DAI}^{\wedge}$ or $\mathrm{ICH}^{\$}$ & $80(25.3 \%)$ & 2.061(1.635- 2.599) & & \\
\hline \multirow[t]{2}{*}{5} & Loss of consciousness at presentation & No & $228(71.9 \%)$ & $0.056(0.025-0.127)$ & \multirow{2}{*}{$\begin{array}{l}1.271 \\
(0.874-2.116)\end{array}$} & \multirow[t]{2}{*}{$\mathrm{P}=0.168$} \\
\hline & & Yes & $89(28.1 \%)$ & $1.844(1.523-2.246)$ & & \\
\hline \multirow[t]{2}{*}{6} & Hypotension & No & $308(97.2 \%)$ & $0.205(0.119-0.351)$ & \multirow[t]{2}{*}{$1.629(0.301-5.101)$} & \multirow[t]{2}{*}{$\mathrm{P}=0.259$} \\
\hline & & Yes & $9(2.8 \%)$ & $2.591(1.027-6.534)$ & & \\
\hline \multirow[t]{2}{*}{7} & Convulsion & No & 291(91.8\%) & $0.136(0.090-0.207)$ & \multirow[t]{2}{*}{$1.244(0.296-0.902)$} & \multirow[t]{2}{*}{$\mathrm{P}=0.816$} \\
\hline & & Yes & $26(8.2 \%)$ & $3.344(1.773-6.307)$ & & \\
\hline \multirow[t]{2}{*}{8} & Comorbid illness & No & $313(98.7 \%)$ & $0.294(0.106-0.812)$ & \multirow[t]{2}{*}{$1.325(0.157-2.124)$} & \multirow[t]{2}{*}{$\mathrm{P}=0.873$} \\
\hline & & Yes & $4(1.3 \%)$ & $1.706(0.64-4.551)$ & & \\
\hline
\end{tabular}

$\mathrm{COR}^{*}$ - crude odd ratio, $\mathrm{AOR}^{* *}$-adjusted odd ratio, $\mathrm{ICP}^{+}$-intracranial pressure, $\mathrm{TBI}^{\#}$-traumatic brain injury $\mathrm{CT}^{\%}$-Computer tomography, $\mathrm{DAI}^{\wedge}$ diffuse axonal injury, $\mathrm{ICH}^{\$}$ - intracranial hemorrhage

\section{Figures}




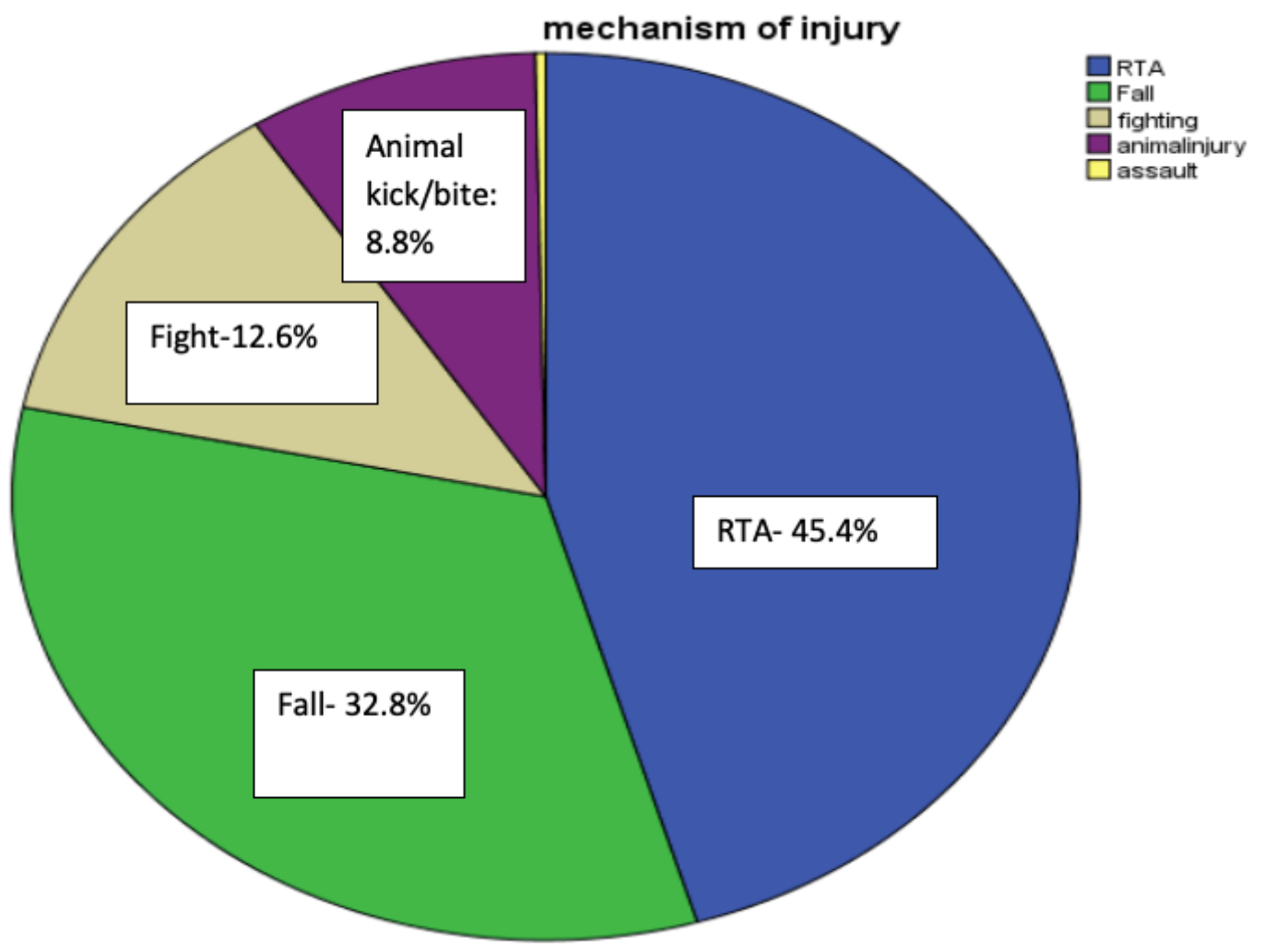

Figure 1

Mechanism of Pediatric traumatic brain injury at HUCSH from September 2017 to September 2018. 